\title{
Klimatske promjene - Potencijalna prijetnja još znatnijoj pojavnosti mikotoksina
}

\author{
J. Pleadin*, M. Zadravec, T. Lešić, J. Frece, V. Vasilj i K. Markov
}

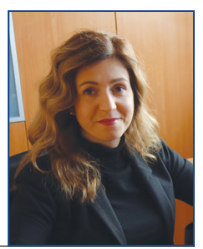

\section{Sažetak}

Tijekom posljednjeg desetljeća znanstvenici sve više ukazuju na globalno zagrijavanje, dovodeći klimatske promjene $\mathrm{u}$ poveznicu $\mathrm{s}$ novom strukturom vrsta plijesni producenata mikotoksina po geografskim područjima svijeta. Izraženije klimatske promjene mogu u budućnosti izmijeniti otpornost domaćina i interakciju domaćin-patogen te imati znatan utjecajna razvoj toksikogenih plijesni i produkciju mikotoksina kao njihovih sekundarnih metabolita. Novonastala klimatološka situacija izaziva sve veću pozornost i zahtijeva nove dijagnostičke alate, kao i nove spoznaje o biološkim karakteristikama poljoprivrednih kultura koje se uzgajaju i genetici toksikogenih plijesni. Zbog sve povoljnijih klimatskih uvjeta za rast Aspergillus flavus na području Europe, $\mathrm{u}$ narednom razdoblju postoji povećani rizik od onečišćenja žitarica izrazito toksičnim aflatoksinima. Ujedno, profil mikotoksigenih vrsta Fusarium počinje se sve znatnije mijenjati, a posebno je zabrinjavajući porast onečišćenja s F. graminearum u sjevernom i središnjem dijelu Europe. S obzirom na očigledne klimatske promjene, potrebna su daljnja istraživanja koja uključuju "prediktivne modele" s više varijabli, a koji bi u bliskoj budućnosti omogućili kvalitetni pristup strategiji prevencije kontaminacije toksikotvornim plijesnima i mikotoksinima u hrani i hrani za životinje.

Ključne riječi: klimatske promjene, mikotoksini, plijesni, okolišni uvjeti, geografska područja, prevencija

\section{Uvod}

Tijekom proizvodnje i skladištenja sirovina, kao i gotovih namirnica, plijesni se pojavljuju kao vrlo učestala onečišćenja koja mogu producirati širok

spektar sekundarnih metabolita, među kojima značajnu skupinu predstavljaju mikotoksini. Za mikotoksine je poznato da prouzroče različite toksične učinke

Dr. sc. Jelka PLEADIN*, dipl. ing. biotehnol., znanstvena savjetnica, izvanredna profesorica (dopisni autor, e-mail: pleadin@veinst.hr), dr. sc. Manuela ZADRAVEC, dr. med. vet., znanstvena suradnica, Tina LEŠIĆ, mag. ing. mol. biotehnol., viša stručna suradnica, doktorandica, Hrvatski veterinarski institut, Zagreb, Hrvatska; dr. sc. Jadranka FRECE, dipl. ing. biotehnol., redovita profesorica, dr. sc. Ksenija MARKOV, dipl. ing. biotehnol., redovita profesorica, Prehrambeno-biotehnološki fakultet Sveučilišta u Zagrebu, Zagreb, Hrvatska; dr. sc. Višnja VASILJ, dipl. ing. agronomije, izvanredna profesorica, Agronomski i prehrambeno-tehnološki fakultet Sveučilišta u Mostaru, Mostar, Bosna i Hercegovina 
u ljudi i životinja, uključujući hepatotoksičnost, nefrotoksičnost, neurotoksičnost, mutagenost, karcinogenost i imunosupresiju (IARC, 1993.). Među stotinama poznatih mikotoksina posebna se pažnja posvećuje aflatoksinima i okratoksinima te fuzarijskim mikotoksinima fumonizinu, zearalenonu, deoksinivalenolu (DON) i T-2/HT-2 toksinu, budući da onečišćuju brojne vrste namirnica, a pojavljuju diljem svijeta (CAST, 2003.).

Ustvrđeno je da razina kolonizacije neke namirnice toksikotvornim plijesnima te vrsta i količina mikotoksina koje one produciraju, ovisi o međudjelovanju niza čimbenika kao što su: vrsta supstrata i dostupnost nutrijenata, udio vlage u supstratu i okolišu, zrelost kolonije, prisustvo drugih vrsta plijesni, kompeticija s drugim mikroorganizmima, oštećenje supstrata uslijed djelovanja insekata i dr. (Magan i sur., 2003., Bhat i sur., 2010., Pleadin i sur., 2018.). Postupci pri uzgoju usjeva, kao i trenutne klimatske prilike, utječu i na pojavnost različitih štetnika, odnosno insekata, koji također mogu prouzročiti kontaminaciju toksikotvornim plijesnima i mikotoksinima.

Od posebnog značenja za produkciju mikotoksina su prevladavajući uvjeti okoliša, odnosno klimatski čimbenici koji karakteriziraju različita geografska područje, a variraju na godišnjoj razini. Istraživanja upućuju da interakcija klimatskih promjena, kao što su povišena koncentracija ugljičnog dioksida, porast temperature te ekstremne izmjene sušnih i kišnih razdoblja, imaju značajan utjecaj na rast plijesni i pojavu mikotoksina (Sinha, 1995., Magan i sur., 2003.). Dugoročne promjene temperature, vlage, količine oborina i učestalost ekstremnih vremenskih pojava već sada utječu na poljoprivrednu praksu, proizvodnju i kvalitetu prehrambenih usjeva. Budući da najnovije spoznaje ukazuju na sve izraženije klimatske promjene, za očekivati je da će one u bliskoj budućnosti znatno utjecati na pojavnost toksikotvornih plijesni te time i na vrstu mikotoksina, kao i njihovu učestalost $u$ različitim geografskim područjima svijeta a predstavljat će važan zdravstveni i ekonomski rizik te izazov za globalnu sigurnost hrane (EFSA, 2020.).

Smatra se da će pitanje klimatskih promjena biti dominantan problem okoliša u 21. stoljeću, a učinci će se očitovati u promjeni količine oborina, povećanju intenziteta i učestalosti ekstremnih meteoroloških pojava, podizanju razine mora, smanjenju zaliha pitke vode, povećanju površine pustinja, povećanju opasnosti od bolesti i izumiranju niza bioloških vrsta. Geografski gledano, previđa se da će najveći rizik od kontaminacije mikotoksinima u poveznici s klimatskim promjenama biti u razvijenim zemljama s umjerenom klimom (Paterson i Lima, 2010.). Više temperature $u$ kombinaciji s ekstremnim količinama oborina ili razdobljima suše povećavaju stres biljaka, dodatno predisponirajući ponajprije kukuruz, ali i ostale žitarice infekciji plijesnima i kontaminaciji mikotoksinima. Može se očekivati veća pojavnost fuzarijskih mikotoksina na sjevernom dijelu Europe te Aspergillus vrsta $u$ njenom središnjem dijelu, $u$ odnosu na prethodno razdoblje $u$ kojem je njihova pojavnost bila više karakteristična za južni dio Europe (Battilani i sur., 2012., 2016.).

U ovom radu dan je pregled dosadašnjih spoznaja i predviđanja po specifičnim geografskim područjima svijeta o utjecaju klimatskih promjena na pojavnost mikotoksina te je istaknuto značenje primjene strategija prevencije $\mathrm{u}$ cilju smanjenja utjecaja klimatskih čimbenika na povećanu kontaminaciju toksikotvornim plijesnima i mikotoksinima kao vrlo značajnim onečiščivaćima hrane i hrane za životinje. 


\section{Produkcije mikotoksina uvjetovane okolišem}

Pojavnost mikotoksina u izravnoj je poveznici s pojavnošću toksikotvornih vrsta plijesni, koje na godišnjoj razini variraju po različitim regijama svijeta te je u ovisnosti o okolišnim uvjetima. Aspergillus vrste dominiraju u toplim i umjerenim dijelovima svijeta, dok su Penicillium vrste česte $\mathrm{u}$ hladnijim dijelovima svijeta (Sweeney i Dobson, 1998.). Stoga se aflatoksini koje uglavnom proizvode Aspergillus vrste u većim koncentracijama nalaze $u$ tropskim i suptropskim područjima, fuzarijski mikotoksini u umjerenom klimatskom području, a okratoksini, koje najviše produciraju plijesni iz roda Penicillium, u područjima hladnije klime. Također, duga sušna razdoblja tijekom godine pogoduju produkciji aflatoksina, dok kišna razdoblja pogoduju nastanku Fusarium mikotoksina (Bhat i sur., 2010., Binder i sur., 2007.). Zaključno, ključni je čimbenik temperatura okoliša koja zajedno s aktivitetom vode $\left(\mathrm{a}_{\mathrm{w}}\right)$ utječe na rast plijesni i proizvodnju mikotoksina (Northolt i Bullerman, 1982.).

U toplim i vlažnim suptropskim i tropskim uvjetima, u različitim vrstama žitarica, primarno u kukuruzu, pojavljuju se idealni uvjeti za kolonizaciju i dominantnostvrstaA.flavusi A.parasiticus, što rezultira produkcijom aflatoksina kao izrazito toksičnih mikotoksina (IARC, 1993.), s najznačajnijim predstavnikom aflatoksinom $B_{1}$. Ovaj mikotoksin često onečišćuje različite vrste hrane, primarno žitarice, među kojima najčešće kukuruz (Pleadin i sur., 2014.a,b). Optimalni uvjeti za proizvodnju aflatoksina su pri temperaturi od $33{ }^{\circ} \mathrm{C}$ i a $a_{w}$ od 0,99 , dok je za rast aflatoksikogenih plijesni potrebna temperatura od $35^{\circ} \mathrm{C} \mathrm{i} \mathrm{a} a_{w}$ od 0,95 (Sanchis i Magan, 2004.).

Okratoksin A je najznačajniji i najtoksičniji predstavnik iz skupine okratoksina, a kontaminant je širokog spektra namirnica, uključujući proizvode od žitarica, orašaste plodove, začine, kavu, grožđice i vino (Zimmerli i Dick, 1996., Urbano i sur., 2001.). Okratoksine proizvodi nekoliko vrsta plijesni iz roda Aspergillus, primarno $A$. ochraceus, $A$. niger, A. carbonarius te roda Penicillium, P. verrucosum (Abarca i sur., 1994., Varga i sur., 1996.). A. ochraceus je pronađen $\mathrm{u}$ velikom broju namirnica, uglavnom u žitaricama, grahu, začinima, suhom voću, orašastim plodovima i sjemenkama (Pleadin i sur., 2018.). Raspon temperatura koje su povoljne za rast $A$. ochraceus je mnogo širi od onog potrebnog za produkciju okratoksina A $\left(8-37{ }^{\circ} \mathrm{C}\right)$ (ICMSF, 1996.). Najveće količine ovog mikotoksina produciraju se pri $\mathrm{a}_{\mathrm{w}} 0,98$, bez obzira na temperaturnu razinu, a njegova najveća proizvodnja je pri $25-30{ }^{\circ} \mathrm{C}$, ovisno o vrstama izolata. Vrsta, odnosno, nutritivni sastav hrane i njezin prehrambeni status vrlo su važni za proizvodnju okratoksina A (Sanchis i Magan, 2004.).

$P$. verrucosum učinkovito kolonizira različite žitarice, posebice $u$ vlažnim i hladnijim klimatskim dijelovima svijeta, naročito $u$ pšenici i ječmu ako nisu dovoljno osušeni. $P$. verrucosum može rasti u širokom temperaturnom rasponu $\left(0-35^{\circ} \mathrm{C}\right)$. Iako je temperatura od $25^{\circ} \mathrm{C}$ optimalna za proizvodnju okratoksina A u zrnju žitarica, producira se i pri $5-10{ }^{\circ} \mathrm{C}$ tijekom dugotrajnog skladištenja u povoljnim uvjetima vlage, pri optimalnom $a_{w}$ između $0,90 \mathrm{i}$ 0,95 i minimalnoj vrijednosti $a_{w} 0,83-0,85$, u ovisnosti i o vremenu skladištenja (Cairns i sur., 2003.). Vrlo je malo podataka dostupno o utjecaju parametara okoliša na produkciju okratoksina A od strane plijesni roda Aspergillus. Battilani i sur. (2003.) i Mitchell i sur. (2003.) dokazali su da se optimalni rast $A$. carbonarius odvija pri 35 ${ }^{\circ} \mathrm{C}$, dok se rast ove plijesni ne odvija pri temperaturi manjoj od $15{ }^{\circ} \mathrm{C}$ i većoj od 45 ${ }^{\circ} \mathrm{C}$, uz optimalni $\mathrm{a}_{\mathrm{w}}$ između 0,93 i 0,99.

Patulin je mikotoksin kojeg produciraju vrste iz rodova Penicillium, 
Aspergillus, Paecilomyces Byssochlamys i Eupenillium. Ovaj mikotoksin se često pronalazi u jabukama kontaminiranim s $P$. expansum, posebno u onima koje su pale na tlo i u kojima je započeo proces truljenja (Pleadin i sur., 2018.). Northolt i sur. (1978.) ispitali su utjecaj okolišnih čimbenika na proizvodnju patulina od strane plijesni $P$. expansum, $P$. patulum i $A$. clavatus te utvrdili raspon temperatura za rast i proizvodnju mikotoksina, za svaku plijesan pojedinačno, $\mathrm{u}$ rasponima od: 0 $-24{ }^{\circ} \mathrm{C}, 4-31^{\circ} \mathrm{C}$ te $12-24{ }^{\circ} \mathrm{C}$, uz najnižu temperaturu potrebnu za proizvodnju patulina od strane $P$. expansum u rasponu $1-4{ }^{\circ} \mathrm{C}$.

Prethodna istraživanja pokazala su optimalan rast za fuzarijske plijesni $F$. culmorum, F. poae, F. avenaceum i $F$. tricinctum pri $20-25{ }^{\circ} \mathrm{C}$, s graničnim vrijednostima pri najnižoj temperaturi od 5 - $10{ }^{\circ} \mathrm{C}$ te najvišoj od $35^{\circ} \mathrm{C}$ (Magan i Lacey, 1984). Navedene fuzarijske plijesni sintetiziraju veći broj fuzarijskih mikotoksina, koji najviše kontaminiraju žitarice (Pleadin i sur., 2013., 2017.). Njihov se optimalni rast postiže u rasponu $\mathrm{a}_{\mathrm{w}} 0,98-0,995$, s minimalnim vrijednostima 0,90 - 0,91, u optimalnom temperaturnom rasponu (Hope i Magan, 2003.).

Versonder i sur. (1982.) dokazali su da sojevi F. graminearum i F. culmorum produciraju DON pri optimalnoj temperaturi od 25 do $30^{\circ} \mathrm{C}$, a minimalna temperatura za njegovu proizvodnju je $11^{\circ} \mathrm{C}$, u ovisnosti o vremenu inkubacije. Proizvodnja DON-a i nivalenola je općenito $u$ dosta užem rasponu $a_{w} i$ temperature nego li za rast fuzarijskih vrsta plijesni. Manje podataka dostupno je o ekološkim profilima proizvodnje zearalenona (Sanchis i Magan, 2004.). Većina izolata F. verticillioides proizvodi ponajprije fumonizin $\mathrm{B} 1$ te manje količine fumonizina B2, B3 i B4. Raspon temperaturnih uvjeta koji utječu na rast ove plijesni je mnogo širi nego za proizvodnju spomenutih fumonizina.
Rast se odvija pri $4-37^{\circ} \mathrm{C}$, s optimalnom temperaturom od oko $30{ }^{\circ} \mathrm{C}$ (Marin i sur., 1999.a), dok se fumonizini najviše produciraju pri $10-37^{\circ} \mathrm{C}$, uz optimalnu temperaturu u rasponu $15-30{ }^{\circ} \mathrm{C}$ (Marin i sur., 1999.b).

\section{Učinci klimatskih promjena}

Istraživanja pokazuju da i okolišni stres ima značajne posljedice za proizvodnju mikotoksina od strane plijesni (Schmidt-Heydt i sur., 2011., Medina i sur., 2015.b,c). Iako su plijesni uglavnom otporne na povišenu koncentraciju ugljičnog dioksida, u kombinaciji s drugim čimbenicima, ovaj plin može imati značajan indirektan utjecaj na produkciju mikotoksina, povezan s faktorima stresa, zbog suše, oštećenja biljaka insektima i promjenama u fenologiji usjeva, poput promjena vremena cvatnje i zrenja žitarica (Van Der Fels-Klerx i sur., 2016., Medina i sur., 2017.).

Novija saznanja govore da se $\mathrm{u}$ sljedećim desetljećima može očekivati porast koncentracije ugljičnog dioksida u atmosferi za dva do tri puta (s 350-400 na 800-1200 ppm) i porast temperature za $2-5{ }^{\circ} \mathrm{C}$, praćen sušnim razdobljima (Gregory i sur., 2009., Bebber i sur., 2013., 2014., Bebber i Gurr, 2015., Medina i sur., 2014., 2017.). Promjene u rastu najznačajnijih vrsta toksikotvornih plijesni i produkciji mikotoksina kao rezultat porasta temperature za 3 i $5{ }^{\circ} \mathrm{C}$ pod različitim uvjetima $a_{w^{\prime}}$ prikazane $s u$ u tabeli 1.

Primjerice, aflatoksini su kancerogeni mikotoksini koje proizvode Aspergillus plijesni, a prisutne su u područjima s vrućom i vlažnom klimom. Smatra se da je rast temperature i vlage povezan s klimatskim promjenama najvjerojatnije rezultirao pojavom znatnije kontaminacije aflatoksinima u južnoj Europi početkom 2000-ih, a od tada je uočena i njihova sve veća razina pojavnosti u sjevernom dije- 


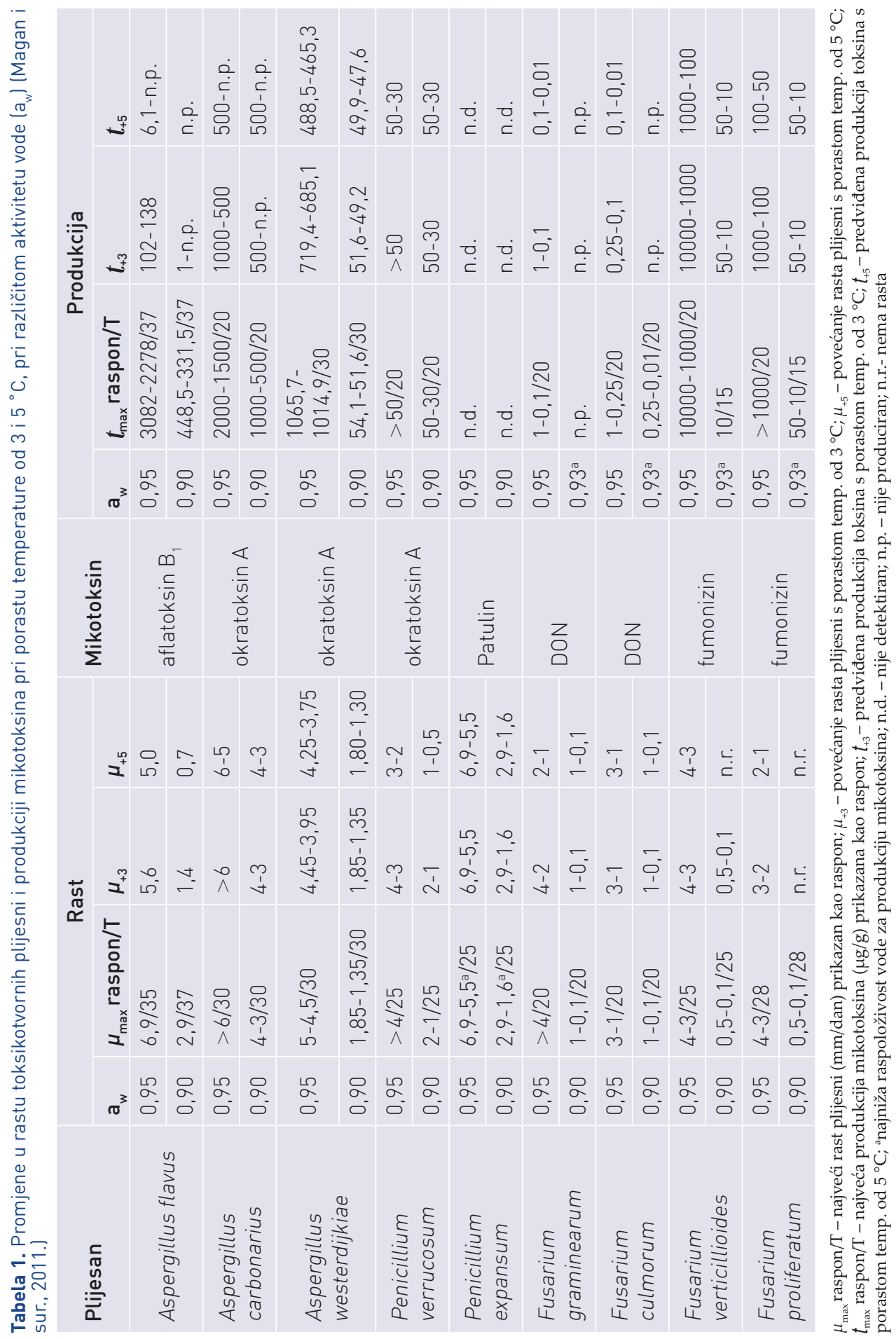


lu Europe. U južnoj su Europi izutetno vruća ljeta već rezultira promjenama u ekosustavima uzgoja kukuruza, što je dovelo do promjena u uobičajenoj pojavnosti vrsta Fusarium i fuzarijskim mikotoksina te učestalijoj pojavnosti $A$. flavus i kontaminaciji izrazito toksičnim aflatoksinom B1. Primjerice, istraživanja provedena u Hrvatskoj ukazala su na visoku kontaminaciju kukuruza aflatoksinima tijekom 2013. godine pod utjecajem tropskih i suptropskih klimatskih uvjeta koji su zabilježeni pri uzgoju kukuruza tijekom 2012. godine (Pleadin i sur. 2014.a, 2015.), dok su ranija istraživanja ukazala na učestaliju kontaminaciju kukuruza i ostalih žitarica fuzarijskim mikotoksinima (Pleadin i sur., 2012.a,b,c; 2013.).

Novija istraživanja $u$ svijetu usmjerena su na proučavanje utjecaja brojnih okolišnih varijabli (npr. temperatura, napada štetočina, dostupnosti hranjivih tvari), na proizvodnju mikotoksina i njihovu pojavnost $\mathrm{u}$ hrani (Paterson i Lima, 2011.). Trenutno su vrlo značajna istraživanja ",prediktivnog modeliranja“ s ciljem identifikacije geografskih regija u kojima može doći do najvećeg utjecaja interaktivnih klimatskih čimbenika u smislu infekcije toksikotvornim plijesnima i posljedične kontaminacije mikotoksinima. Dobivena saznanja stavljaju se $u$ vezu s prehrambenim lancem i utjecajem koji interakcijski klimatski čimbenici mogu imati na dostupnost hrane u budućnosti. Važno je istaknuti i da se mikotoksini učestalo pojavljuju zajednički te da imaju sinergističke učinke u organizmu (Pleadin i sur., 2018.), zbog čega se intenzivno provode istraživanja razvoja modela za procjenu rizika $u$ slučaju kontaminacije većim brojem mikotoksina.

Europska agencija za sigurnost hrane (EFSA) predviđa da će učinci klimatskih promjena na pojavnost mikotoksina biti regionalni te uglavnom štetni, ali moguće i povoljni za pojedino geografsko područje (Battilani i sur., 2012., EFSA, 2020.). Za očekivati je da će klimatske promjene utjecati i na globalne promjene u pojavnosti i geografskoj distribuciji insekata (Bebber i sur., 2014., Bebber i Gurr, 2015., Medina i sur., 2015.a), za koje se zna da imaju značajan utjecaj na infekciju usjeva toksikotvornim plijesnima te da mogu utjecati na povećanu kontaminaciju. Istraživanja pokazuju da klimatske promjene mogu biti odgovorne za trećinu varijabilnosti u prinosu hrane na globalnoj razini i to za ključne i osnovne namirnice te negativno utjecati na njihovu nutritivnu vrijednost (Ramos i sur., 1998., EFSA, 2020.).

Povećana se razina onečišćenja hrane za ljude i za živitinje može pojaviti vezano za trenutno postojeće mikotoksine ili se može dogoditi "premještanje" nekih mikotoksina iz dosadašnjih $u$ nove geografske regije, u kojima ranije nisu zabilježene njihove značajnije razine. Stres prouzročen klimatskim promjenama može rezultirati pojavnošću novih mikotoksina koji ranije nisu bili prepoznati, a njihova pojavnost može ozbiljno narušiti dostupnost hrane i hrane za životinje, posebno u zemljama u razvoju (Miraglia i sur., 2009.).

\section{Predviđanja po geografskim područjima}

Ustvrđeno je da je u posljednjem stoljeću globalna temperatura porasla za $0,7{ }^{\circ} \mathrm{C}$, a u Europi za $1{ }^{\circ} \mathrm{C}$. Količina oborina tijekom istog razdoblja $u$ sjevernoj Europi je porasla za 10 - 40 \%, a u južnoj Europi smanjila. Učestalost suša, toplotnih valova i ekstremnih oborina u Europi je porasla, dok je smanjena učestalost hladnih ekstrema. Najtoplija godina $u$ Europi bila je 2000., a sedam najtoplijih godina bilo je $\mathrm{u}$ posljednjih 14 godina. Projekcije pokazuju da bi u idućem stoljeću porast 
globalne prosječne godišnje temperature mogao iznositi $1,4-5,8{ }^{\circ} \mathrm{C}$, a u Europi $2,0-6,3{ }^{\circ} \mathrm{C}$. Projekcije prikazuju i da će hladne zime gotovo potpuno nestati do kraja stoljeća, a topla ljeta da će biti sve učestalija (MZOP, 2020.).

Očekuje se da će u Europi, naročito njezin južni dio, biti pogođen klimatskim promjenama, gdje će se dogoditi kombinirane promjene po pitanju povišenog udjela ugljičnog dioksida $\mathrm{u}$ atmosferi (dva puta u odnosu na prosječnu razinu $u$ posljednjim desetljećima), porasta temperature (za 2 $4{ }^{\circ} \mathrm{C}$ ) i pojave ekstremnih oborina i suša. Slični se utjecaji očekuju u dijelovima Sjeverne i Južne Amerike, npr. za Brazil te Afriku i Aziju (Paterson i Lima, 2011.). Predikcijski modeli pokazuju da bi sjeverna Europa mogla imati pozitivne učinke, dok mediteranska regija može biti žarište s brojim negativnim utjecajima u smislu ekstremnih promjena $u$ količinama padalina, sušama, povišenim temperaturama i razini ugljičnog dioksida. Sazrijevanje kultura u južnoj i srednjoj Europi može se očekivati dosta ranije $\mathrm{u}$ odnosu na uobičajeno razdoblje. U pojedinim zemljama južne i jugoistočne Europe (Portugal, Spanjolska, južna Francuska, Italija, Slovenija, Grčka, Malta, Cipar, Bugarska i južna Rumunjska) predviđa se porast temperature za 4 - $5{ }^{\circ} \mathrm{C}$ i smanjena raspoloživost vode, posebice ljeti. Zemlje zapadne i atlantske Europe (npr. Beneluks, zapadna i sjeverna Francuska, sjeverna Njemačka, Ujedinjeno Kraljevstvo, Republika Irska, Nizozemska i Danska) imat će porast od $2,5-3,5{ }^{\circ} \mathrm{C}\left(2-3{ }^{\circ} \mathrm{C}\right.$ za Veliku Britaniju i Republiku Irsku) sa sušnim i toplijim ljetima (Paterson i Lima, 2011.).

Zbog većih količina i intenziteta oborina predviđa se da će jake oluje i poplave biti učestalije, osobito zimi. U Norveškoj, Švedskoj, Finskoj i baltičkim državama (sjeverna Europa) očekuje se povećanje temperature $\mathrm{u}$ rasponu $3-4,5$ ${ }^{\circ} \mathrm{C}$ i porast godišnjih količina oborina do $40 \%$, s visokim rizikom od poplava (EC, 2007.). U području središnje Europe (Poljska, Češka, Slovačka, Mađarska, sjeverna Rumunjska, južna i istočna Njemačka i istočna Austrija) predviđa se porast za $3-4{ }^{\circ} \mathrm{C}\left(4-4,5{ }^{\circ} \mathrm{C}\right.$ za srednjoeuropsku i crnomorsku regiju), a oborine se mogu povećavati zimi i smanjivati ljeti, uz povećan rizik od poplava.

Može se očekivati da će klimatske promjene općenito jako utjecati na kontaminaciju različitih žitarica aflatoksinima te da će uslijed povećane kontaminacije aflatoksikogenim plijesnima njihov najtoksičniji predstavnik aflatoksin $\mathrm{B}_{1} \mathrm{u}$ narednom stoljeću postati značajna prijetnja sigurnosti hrane, primarno na području istočne Europe, na Balkanskom poluotoku i Mediteranu (Battilani i sur., 2012., 2016.). Modeliranjem utjecaja potencijalnih klimatskih promjena na fenologiju pšenice na području sjeverozapadne Europe, predviđa se ranija cvatnja i zrenje ozime pšenice $\mathrm{i}$ to između jednog i dva tjedna, kao i povećana kontaminacija usjeva DON-om (Van Der Fels-Klerx i sur., 2016.).

Procjenjuje se da će Australija postati previše vruća, uz drastičan porast temperature do 2100. godine i duga sušna razdoblja te da će se zbog porasta temperature i problema s raspoloživosti vode biti onemogućen uzgoj mnogih kultura (Chakraborty i sur., 1998., Paterson i Lima, 2011.). Rizik od kontaminacije mikotoksinima u daljnjem razdoblju teže je ustvrditi za Aziju, budući da za taj kontinent nedostaju relevantni podatci. Svakako se može očekivati veća šteta od poplava, veći ulazak plijesni putem oštećenog usjeva, a posljedično i povećane razine mikotoksina. Međutim, u trenutno vrućim klimama (IPCC, 2007.) temperatura može postati izuzetno visoka što dovesti i do izumiranja pojedinih plijesni. Primjerice, $u$ istraživanju Iqbal i sur. (2011.) o aflatoksinima u čiliju, pri 
temperaturi od $53,7{ }^{\circ} \mathrm{C}$ zabilježenoj $\mathrm{u}$ Pakistanu, ustvrđena je smanjena razina kontaminacije plijesnima, a time i ovim mikotoksinima.

U Latinskoj se Americi previđa scenarij znatnijeg porasta temperature i smanjenja vode $u$ tlu. Tropska šuma postat će savanski travnjak, a polusušne kopnene kulture zamijenit će se suhom vegetacijom. Doći će do znatnog izumiranja tropskih vrsta i smanjenja produktivnosti usjeva (IPCC, 2007.). U Sjevernoj Americi poplave i visoka temperatura rezultirat će problemima pri skladištenju, što će pogodovati rastu plijesni i proizvodnji mikotoksina. Proizvodnja tropskih kultura poput kokosa, kukuruza, soje, kave i kakaa može postati optimalna $\mathrm{u}$ trenutno suptropskim regijama, poput južnog dijela SAD-a (Pritchard, 2011.). Ako pretpostavimo da tropsko vrijeme postaje uobičajena pojava $\mathrm{u}$ trenutno subtropskim regijama, može se općenito smatrati pozitivnim pa se razvijene zemlje mogu bolje nositi s povećanom kontaminacijom mikotoksinima koje se mogu očekivati u tropskim kulturama, $\mathrm{u}$ odnosu na zemlje u razvoju (Paterson i Lima, 2011.).

\section{Strategija prevencije}

Prevencija kontaminacije prehrambenih sirovina mikotoksinima općenito se smatra važnijom od naknadnog suzbijanja. Stoga se trebaju primjenjivati i u stalnom su razvoju procesi analize opasnosti i kontrole kritičnih točaka putem HACCP sustava (engl. Hazard Analysis and Critical Control Point). Primjena HACCP obuhvaća cijeli niz preventivnih postupaka kako bi se definirale kritične kontrolne točke u kojima mikotoksikogene plijesni i mikotoksini mogu ući u prehrambeni lanac s krajnjim ciljem osiguravanja zdravstveno ispravne hrane.

Uzimajući u obzir zajedničku pojavnost većeg broja mikotoksina $u$ pojedinim sirovinama te posljedično i u gotovim proizvodima, pri razvoju strategija prevencije kontaminacije mikotoksinima i spriječavanja pojavnosti mikotoksikoza vrlo značajne su spoznaje o njihovim interakcijama. Nadzor, odnosno, prevenciju kontaminacije nužno je usmjeriti i u pogledu klimatskih čimbenika. Važno je razumjeti optimalne i granične uvjete temperature i relativne vlage za rast i proizvodnju mikotoksina, posebno kod ključnih vrsta plijesni (Aspergillus, Penicillum i Fusarium). Temeljem tih podataka potrebno je provesti sušenje i skladištenje sirovina i gotovih namirnica pod uvjetima koji ne dopuštaju kolonizaciju toksikotvornih plijesni i produkciju mikotoksina (Pleadin i sur., 2018.).

Strategija minimiziranja kontaminacije $\mathrm{u}$ poveznici $\mathrm{s}$ utjecajem klimatskih čimbenika uključuje uporabu relativno otpornih kultivara, učinkovite poljoprivredne prakse prije žetve, primjenu kemijskih ili bioloških tretmana za štetočine, infekciju gljivicama i regionalno sagledavanje vremenskih uvjeta. Strategija sadnje za određeni usjev trebala bi ovisiti o prevladavajućim klimatskim uvjetima, uzimajući u obzir lokalne usjeve $\mathrm{i}$ trenutnu proizvodnu praksu u nekim zemljama, odnosno regijama. Ključni čimbenici za kontrolu kontaminacije predstavljaju: plodored, agrotehniku, izbor sorte ili hibrida i pravilnu uporabu fungicida.

Zitarice treba sušiti na način da razina vlage bude niža od razine potrebite za rast plijesni tijekom skladištenja. Aktivitet vode manji od 0,65 uglavnom odgovara sadržaju vlage manjem od $15 \%$, što je značajno u prevenciji rasta brojnih vrsta plijesni koje mogu biti prisutne u svježem žitu. Često samo mala promjena $\mathrm{u}$ udjelu vlage $(<0,5$ \%) može dovesti do kontaminacije namirnica mikotoksinima iznad najvećih dopuštenih količina (Sanchis i Magan, 2004.). Nadalje, trebaju se 
uvesti postupci za pravilno rukovanje, kroz segregaciju, obnavljanje, opoziv ili preusmjeravanje uporabe za žitarice koje mogu predstavljati opasnost za zdravlje ljudi i životinja (Pleadin i sur., 2018.).

Prilikom sušenja treba izbjegavati radnje kojima se oštećuje zrno žitarica. Najvažnije je da razdoblje tijekom kojeg se mokro, svježe požnjeto žito čuva na gomili prije sušenja ili čišćenja bude što je moguće kraće, kako bi se smanjio rizik od rasta plijesni. Održavanje higijenskih uvjeta, kako u pogledu zagađenja štetočinama, tako i plijesni, predstavljaju kritične točke tijekom srednjoročnog i dugoročnog skladištenja te tijekom prijevoza robe, budući da se na globalnom tržištu sirovine i gotovi proizvodi prevoze na velike udaljenosti kroz različite klimatske uvjete. Mnogi prehrambeni proizvodi su higroskopni i lako apsorbiraju vodu, čime je omogućen rast toksikotvornih plijesni te kontaminacija mikotoksinima. Stoga je potrebno osigurati čistu i suhu ambalažu, spriječiti mogućnost prisustva insekata te kroz skladišni prostor osigurati strujanje zraka kako bi se održala odgovarajuća i stalna razina temperature.

Uzimajući u obzir klimatske faktore potrebno je definirati i korištenje prikladnih, registriranih insekticida i fungicida ili odgovarajućih alternativnih metoda uz pažljiv odabir kemikalija koje neće prouzročiti štetu, ujedno u ovisnosti o planiranoj krajnjoj uporabi žita, pri čemu njihovo korištenje treba biti strogo ograničeno. Da bi mjere kontrole bile učinkovite, od ključne je važnosti raspoloživost relevantnih informacija o ekofiziološkim utjecajima abiotskog i biotskog stresa $u$ toksikotvornih plijesni za nastanak mikotoksina. Ove su informacije ključne za bolje razumijevanje i praćenje najznačajnijih kritičnih kontrolnih točaka pri proizvodnji hrane, kako bi se optimizirale strategije prevencije $u$ svim fazama prehrambenog lanca.
Po pitanju klimatskih promjena, poznato je da prilikom izgaranja fosilnih goriva $\mathrm{u}$ industrijama dolazi do emisije ugljičnog dioksida, a da je njegovo uklanjanje iz atmosfere smanjeno zbog sve manjih površina prekrivenih šumama kao najznačajnijim potrošačima ugljičnog dioksida. Povećana koncentracija ovog stakleničkog plina u atmosferi prouzroči povećanu apsorpciju topline, što dovodi do promjena temperature zraka, količine oborina i ostalih klimatoloških elemenata. Uvažavajući navedene činjenice nužno je prevenciju kontaminacije mikotoksinima sagledati i u smjeru globalnog smanjenjenja proizvodnje ugljičnog dioksida, odnosno općenito smanjenja zagađenja okoliša.

\section{Budući aspekti}

Poznato je da kontaminacija hrane i hrane za životinje mikotoksinima trenutno prouzroči velike troškove diljem svijeta, a trošak će se gotovo sigurno povećavati s intenziviranjem klimatskih ekstrema. Stoga bi izrada „prediktivnih modela" omogućila kratkotrajno i dugoročno planiranje kontrole mikotoksina i rukovanje žitaricama te marketinšku strategiju kojom bi se osigurala ekonomska održivost, kao i sigurna opskrba hranom za ljude i životinje.

Definirana su četiri glavna područja istraživanja koja su potrebita kako bi se dobili korisni podatci o budućem utjecaju klimatskih promjena na rizik od mikotoksina (Wu i sur., 2011.): (i) koristiti raspoložive simulacije budućih klimatskih scenarija na regionalnoj razini; (ii) koristiti već postojeće podatke te provesti dodatna istraživanja s ciljem prikupljanja podataka o tome kako klimatski uvjeti u budućnosti mogu utjecati na pojavnost različitih vrsta plijesni i koncentraciju mikotoksina; (iii) razviti modele koji predviđaju razine najznačajnijih mikotoksina, aflatoksina, fumonisina i DON-a, primarno $u$ 
kukuruzu, ali i ostalim žitaricama, uzimajući u obzir buduće klimatske scenarije; (iv) provesti istraživanja o utjecaju klimatskih promjena na sigurnost hrane u bližoj i daljoj budućnosti, u smislu ekonomskih i zdravstvenih rizika povezanih s mikotoksinima.

Primarno je potrebito istražiti najznačajnije vrste plijesni producenata mikotoksina iz rodova Aspergillus, Penicillium i Fusarium. Daljnja istraživanja trebaju biti usmjerena na utjecaj različitih scenarija po pitanju klimatskih promjena, uzimajući u obzir interakciju između povišene razine ugljičnog dioksida, temperature i stresa od suše. Iako postoji nekoliko modela koji povezuju klimatske faktore $s$ pojavnošću pojedinih mikotoksina (npr. De la Campa i sur., 2005., Schaafsma i Hooker, 2007., Chauhan i sur., 2008., Maiorano i sur., 2009., Rossi i sur., 2009.), istraživanja za veći broj mikotoksina i različite vrste žitarica te njihovu potencijalnu pojavnost, tek trebaju biti provedena. Izrada utemeljenih modela kao posljedice klimatskih promjena omogućila bi proizvođačima i kupcima predvidjeti buduću pojavnost plijesni i kontaminaciju mikotoksinima. Činjenica je da se klima mijenja izvan okvira koji se mogu povezati isključivo $\mathrm{s}$ prirodnom varijabilnošću, a pri sagledavanju posljedica klimatskih promjenama teško je odrediti udio ljudske odgovornosti. Međutim, poboljšanje kvalitete zraka, na koju ljudski faktor ima utjecaj, zasigurno može potaknuti napore da se ublaže globalno svakim danom sve izraženije klimatske promjene.

\section{Zahvala}

Istraživanja u ovom području financiraju se iz projekta Hrvatske zaklade za znanost „Mikotoksini u hrvatskim tradicionalnim mesnim proizvodima: molekularna identifikacija plijesni producenata i procjena izloženost potrošača“ (HRZZ IP-2018-019017).

\section{Literatura}

1. ABARCA, M. L., M. R. BRAGULAT, G. CASTELLA and F. J. CABANES (1994): Ochratoxin A production by strains of Aspergillus niger var. niger. Appl. Environ. Microbiol. 60, 2650-2652.

2. BATTILANI, P., A. PIETRI, P. GIORNI, T. BERTUZZI and C. CARBANO (2003): Growth and ochratoxin A production of Aspergillus section Nigri isolates from Italian grapes. Asp. Appl. Biol. 68, 175180.

3. BATTILANI, P., P. TOSCNO, H. J. VAN DER FELSKLERX, A. MORETTI, M. C. LEGGIERI, C. BRERA, A. RORTAIS, T. GOUMPERIS and T. ROBINSKON (2016): Aflatoxin B1 contamination in maize in Europe increases due to climate change. Sci. Rep. 6, 24328 .

4. BATTILANI, P., V. ROSSI, P. GIORNI, A. PIETRI, A. GUALLA, H. J. VAN DER FELS-KLERX, C. J. H. BOOIJ, A. MORETTI, A. LOGRIECO, P. TOSCANO, M. MIRAGLIA, B. DE SANTIS and C. BRERA (2012): Modelling, predicting and mapping the emergence of aflatoxins in cereals in the EU due to climate change. Scientific/-Technical Report submitted to EFSA. Dostupno na: http://www.efsa. europa.eu/en/supporting/pub/223e.htm.

5. BEBBER, D. P., M. A. T. RAMOTOWSKI and S. J. GURR (2013): Crop pests and pathogens move poleward in a warming world. Nat. Clim. Change 3, 985-988.

6. BEBBER, D. P. and S. J. GURR (2015): Cropdestroying fungal and oomycete pathogens challenge food security. Fungal Gen. Biol. 74, 62-64.

7. BEBBER, D. P., T. HOLMES and S. J. GURR (2014): The global spread of crop pests and pathogens. Global Ecol. Biogeogr. 23, 1398-1407.

8. BHAT, R., R. V. RAI and A. A. KARIM (2010): Mycotoxins in food and feed. Present status and future concerns. Compr. Rev. Food Sci. Food Saf. 9, 57-81.

9. BINDER, E. M., L. M. TAN, L. J. CHIN, J. HANDL and J. RICHARD (2007): Worldwide occurrence of mycotoxins in commodities, feeds and feed ingredients. Anim. Feed Sci. Technol. 137, 265-282.

10. CAIRNS, V., R. HOPE and N. MAGAN (2003): Environmental factors and competing mycoflora affect growth and ochratoxin production by Penicillium verrucosum on wheat grain. Asp. Appl. Biol. 68, 81-90.

11. CAST (2003): Mycotoxins: risks in plant, animal, and human systems. Task Force Report 139 Ames, Iowa: Council for Agricultural Science and Technology.

12. CHAKRABORTY, S., G. M. MURRAY, P. A. MAGAREY, T. YONOW, R. G. O'BRIEN, B. J. CROFT, M. J. BARBETTI, K. SIVASITHAMPARAM, K. M. OLD, M. J. DUDZINSKI, R. W. SUTHERST, L. J. PENROSE, C. ARCHER and R. W. EMMETT (1998): Potential impact of climate change on plant diseases of economic significance to Australia. Australas. Plant Path. 27, 15-35. 
13. CHAUHAN, Y., G. WRIGHT and N. RACHAPUTI (2008): Modelling climatic risks of aflatoxin contamination in maize. Aust. J. Exp. Agric. 48, 358-366.

14. DE LA CAMPA, R., D. C. HOOKER, J. D. MILLER, A. W. SCHAAFSMA and B. G. HAMMOND (2005): Modeling effects of environment, insect damage, and $\mathrm{Bt}$ genotypes on fumonisin accumulation in maize in Argentina and the Philippines. Mycopathologia 159, 539-552.

15. EC (European Commission) (2007): Adapting to climate change in Europe - Options for EU action. Green paper from the Commission to the Council, the European Parliament, the European Economic and Social Committee and the Committee of the Regions, COM, 354 final, SEC, 849. Brussels: European Commission.

16. EFSA (European Food Safety Authority), MAGGIORE, A., A. AFONSO, F. BARRUCCI, G. DE SANCTIS (2020): Climate change as a driver of emerging risks for food and feed safety, plant, animal health and nutritional quality. EFSA supporting publication 2020: EN-1881. 147. pp. doi:10.2903/ sp.efsa.2020.EN-1881. Dostupno na: https:// efsa.onlinelibrary.wiley.com/doi/epdf/10.2903/ sp.efsa.2020.EN-1881.

17. GREGORY, P. J., S. N. JOHNSON, A. C. NEWTON and J. S. I. INGRAM (2009): Integrating pests and pathogens into the climate change/food security debate. J. Exp. Bot. 60, 2827-2838.

18. HOPE, R. and N. MAGAN (2003): Two dimensional environmental profiles of growth, deoxynivalenol and nivalenol production by Fusarium culmornm on a wheat-based substrate. Lett. Appl. Microbiol. 37, 70-74.

19. IARC (International Agency for Research on Cancer) (1993): IARC Monographs on the Evaluation of Carcinogenic Risks to Humans, Vol 56. Some naturally occurring sub stances: food itemsand constituents, heterocyclic amines and mycotoxins, Lyon, IARC, 489-521.

20. ICMSF (International Commission on Microbiological Specification for Foods) (1996): Toxigenic fungi: Aspergillus in ICMSF, Microorganisms in foods. Characteristics of Food Pathogens. London, Blackie Academic and Professional, 347-381.

21. IPCC (The Intergovernmental Panel on Climate Change) (2007): Intergovernmental panel on climate change report. Climate Change 2007. Synthesis Report, 52.

22. IQBAL, S. Z., R. R. M. PATERSON, I. A. BHATTI and M. R. ASI (2011): Comparing aflatoxin contamination in chilies from Punjab, Pakistan produced in summer and winter. Mycotoxin Res. 27, 75-80.

23. MAGAN, N., A. MEDINA and D. ALDRED (2011) Possible climate-change effects on mycotoxin contamination of food crops pre-and postharvest. Plant Pathol. 60, 150-163.

24. MAGAN, N., D. ALDRED and V. SANCHIS (2003): Role of fungi in seed deterioration. In: Arora, D. Fungal biotechnology in agricultural, food and environmental applications. New York, Marcel Dekker (311-323).

25. MAGAN, N. and J. LACEY (1984): The effect of temperature and $\mathrm{pH}$ on the water relations of field and storage fungi. Trans. Br. Mycol. Soc. 82, 71-81.

26. MAIORANO, A., A. REYNERI, D. SACCO, A. MAGNI and C. RAMPONI (2009): A dynamic risk assessment model (FUMAgrain) of fumonisin synthesis by Fusarium verticillioides in maize grain in Italy. Crop Prot. 28, 243-256.

27. MARIN, S., N. MAGAN, J. SERRA, A. J. RAMOS, R. CANELA and V. SANCHIS (1999a): Fumonisin B1 production and growth of Fusarium moniliforme and Fusarium proliferatum on maize, wheat, and barley grain. J. Food Prot. 64, 921-924.

28. MARIN, S., N. MAGAN, N. BELLI, A. J. RAMOS, R. CANELA and V. SANCHIS (1999b): Twodimensional profiles of fumonisin B1 production by Fusarium monilifonne and Fusarium proliferatum inrelation to environmental factors and potential for modelling toxin formation in maize grain. Int. J. Food Microbiol. 51, 159-167.

29. MEDINA, A., A. RODRIGUEZ and N. MAGAN (2014): Effect of climate change on Aspergillus flavus and aflatoxins. Front. Microbiol. 5, 348, 1-7.

30. MEDINA, A., A. RODRIGUEZ and N. MAGAN (2015a): Changes in environmental factors driven by climate change: effects on the ecophysiology of mycotoxigenic fungi. In: L. M. Botana, M. J. Sainz: Climate change and Mycotoxins, De Gruyter, Berlin (71-85).

31. MEDINA, A., A. RODRIGUEZ and N. MAGAN (2015b): Climate change and mycotoxigenic fungi: impacts on mycotoxin production. Curr. Opin. Food Sci. 5, 99-104.

32. MEDINA, A., A. RODRÍGUEZ, Y. SULTAN and N. MAGAN (2015c): Climate change factors and A. flavus: effects on gene expression, growth and aflatoxin production. World Mycotoxin J. 8, 171-179.

33. MEDINA, A., A. AKBAR, A. BAAZEEM, A RODRIGUEZ and N. MAGAN (2017): Climate change, food security and mycotoxins: Do we know enough? Fungal Biol. Rev. 31, 143-154.

34. MZOP (Ministarstvo zaštite okoliša i prirode) (2020): Više o učinku staklenika. Dostupno na: http://klima.mzoip.hr/default.aspx?id=43, pristupljeno: 21. kolovoza 2019.

35. MIRAGLIA, M., H. J. P. MARVIN, G. A. KLETER, P. BATTILANI, C. BRERA, E. CONI, F. CUBADDA, L. CROCI, B. DE SANTIS, S. DEKKERS, L. FILIPPI, R. W. A. HUTJES, M. Y. NOORDAM, M. PISANTE, G. PIVA, A. PRANDINI, L. TOTI, G. J. VAN DEN BORN and A. VESPERMANN (2009): Climate change and food safety: An emerging issue with special focus on Europe. Food Chem. Toxicol. 47, 1009-1021.

36. MITCHELL, D., D. ALDRED and N. MAGAN (2003): Impact of ecological factors on growth and ochratoxin A production by Aspergillus carbonarius from different regions of Europe. Asp. Appl. Biol. $68,109-116$ 
37. NORTHOLT, M. D., H. P. VAN EGMOND and W. E. PAULSCB (1978): Patulin production by some fungal speciesin relation to water activity and temperature. J. Food Prot. 41, 885-890.

38. NORTHOLT, M. D. and L. B. BULLERMAN (1982): Prevention of mould growth and toxin production through control of environmental conditions. J. Food Prot. 45, 519-526.

39. PATERSON, R. R. M. and N. LIMA (2010): How will climate change affect mycotoxins in food? Food Res. Int. 43, 1902-1914.

40. PATERSON, R. R. M. and N. LIMA (2011): Further mycotoxin effects from climate change. Food Res. Int. 44, 2555-2566.

41. PLEADIN, J., A. VULIĆ, N. PERŠI, M. ŠKRIVANKO, B. CAPEK and Ž. CVETNIĆ (2015): Annual and regional variations of aflatoxin B1 levels seen in grains and feed coming from Croatian dairy farms over a 5-year period. Food Control 47, 221-225.

42. PLEADIN, J., A. VULIĆ, N. PERŠI, M. ŠKRIVANKO, B. CAPEK and Ž. CVETNIĆ (2014a): Aflatoxin B1 occurrence in maize sampled from Croatian farms and feed factories during 2013. Food Control 40, 286-291.

43. PLEADIN, J., K. MARKOV, J. FRECE, A. VULIĆ and N. PERŠI (2014b): Bio-Prevalence, determination and reduction of aflatoxin B1 in cereals. In: Faulkner, A. G.: Aflatoxins: Food Sources, Occurrence and Toxicological Effects. Nova Science Publishers, USA (1-34).

44. PLEADIN, J., M. MALENICA STAVER, K. MARKOV, J. FRECE, M. ZDRAVEC, V. JAKI, I. KRUPIĆ and N. VAHČIĆ (2017): Mycotoxins in organic and conventional cereals and cereal products grown and marketed in Croatia. Mycotoxin Res. 33, 219-227.

45. PLEADIN, J., M. ZADRAVEC, N. PERŠI, A. VULIĆ, V. JAKI and M. MITAK (2012a): Mould and mycotoxin contamination of pig feed in northwest Croatia. Mycotoxin Res. 28, 157-162.

46. PLEADIN, J., N. PERŠI, M. MITAK, M. ZADRAVEC, M. SOKOLOVIĆ and A. VULIĆ (2012b): The natural occurrence of T-2 toxin and fumonisins in maize samples in Croatia. Bull. Environ. Contam. Toxicol. 88, 863-866.

47. PLEADIN, J., M. SOKOLOVIĆ, N. PERŠI, M. ZADRAVEC, V. JAKI and A. VULIĆ (2012c): Contamination of maize with deoxynivalenol and zearalenone in Croatia. Food Control 28, 94-98.

48. PLEADIN, J., N. VAHČIĆ, N. PERŠI, D. ŠEVELJ, K. MARKOV and J. FRECE (2013): Fusarium mycotoxins' occurrence in cereals harvested from Croatian fields. Food Control 32, 49-54.

49. PLEADIN, J., V. VASILJ i D. PETROVIĆ (2018): Mikotoksini: pojavnost, prevencija i redukcija. Mostar: Sveučilište u Mostaru.

50. PRITCHARD, S. G. (2011): Soil organisms and global climate change. Plant Pathol. 60, 82-99.
51. RAMOS, A. J., N. LABERNIA, S. MARIN, V. SANCBIS and N. MAGAN (1998): Effect of water activity and temperature on growth and ochratoxin production by three strains of Aspergillus ochraceus on a barley extractmedium and on barley grains. Int. J. Food Microbiol. 44, 133-140.

52. ROSSI, V., A. SCANDOLARA and P. BATTILANI (2009): Effect of environmental conditions on spore production by Fusarium verticillioides, the causal agent of maize ear rot. Eur. J. Plant Pathol. 123, 159-169.

53. SANCHIS, V. and N. MAGAN (2004): Environmental conditions affecting mycotoxins. In: Magan, N., M. Olsen: Mycotoxins in Food. Woodhead Publishing Series in Food Science, Technology and Nutrition, Woodhead Publishing (174-189).

54. SCHAAFSMA, A. W. and D. C. HOOKER (2007): Climatic models to predict occurrence of Fusarium toxins in wheat and maize. Int. J. Food Microbiol. 119, 116-125.

55. SCHMIDT-HEYDT, M., R. PARRA, R. GEISEN and N. MAGAN (2011): Modelling the relationship between environmental factors, transcriptional genes and deoxynivalenol mycotoxin production by two Fusarium species. J. Royal Soc. Interface 8, 117-120.

56. SINHA, R. N. (1995): Thestored-grain ecosystem. In: Jayas, D. S., N. D. G. White, W. E. Muir: Stored Grain Ecosystems. New York, Marcell Dekker (1-32).

57. SWEENEY M. J. and A. D. W. DOBSON (1998): Mycotoxin production by Aspergillus, Fusarium and Penicillium species. Int. J. Food Microbiol. 43, 141-158.

58. URBANO, G. R., M. H. TANIWAKI, M. F. LEIATAO and M. C. VICENTINI (2001): Occurrence of ochratoxin A-producing fungi in raw Brazilian coffee. J. Food Prot. 64, 1226-1230.

59. VAN DER FELS-KLERX, H. J., C. LIU and P. BATTILANI (2016): Modelling climate change impacts on mycotoxin contamination. World Mycotoxin J. 9, 717-726.

60. VARGA, J., E. KEVEI, E. RINYU, J. TEREN and Z. KOZAKIEWICZ (1996): Ochratoxin production by Aspergillus species. Appl. Environ. Microbiol. 62, 4451-4464.

61. VERSONDER, R. F., J. J. ELLIS, W. F. KWOLEK and D. J. DEMARINI (1982): Production of vomitoxin oncorn by Fusarium graminearum NRRL 5883 and Fusarium roseum NRRL 6101. Appl. Environ. Microbiol. 43, 967-970.

62. WU, F., D. BHATNAGAR, T. BUI-KLIMKE, I. CARBONE, R. L. HELLMICH, G. P. MUNKVOLD, P. PAUL, G. PAYNE and E. S. TAKLE (2011): Climate change impacts on mycotoxin risks in US maize. World Mycotoxin J. 4, 79-93.

63. ZIMMERLI, B. and R. DICK (1996): Ochratoxin A in table wine and grape-juice: occurrence and risk assessment. Food Addit. Contam. 13, 655-668. 


\section{Climate change - A potential threat for increasing occurrences of mycotoxins}

Jelka PLEADIN, B.Sc. Biotehnol., PhD, Scientific Advisor, Associate Professor, Manuela ZADRAVEC, DVM, PhD, Scientific Associate, Tina LEŠIĆ, B.Sc. Mol. Biotehnol., Senior Scientific Associate, PhD student, Croatian Veterinary Institute, Zagreb, Croatia; Jadranka FRECE, B.Sc. Biotehnol., PhD, Full Professor, Ksenija MARKOV, B.Sc. Biotehnol., PhD, Full Professor, Faculty of Food Technology and Biotechnology, University of Zagreb, Zagreb, Croatia; Višnja VASILJ, B.Sc. Agronom., Associate Professor, Faculty of Agriculture and Food Technology, University of Mostar, Mostar, Bosnia and Herzegovina

Over the last decade, scientists have increasingly pointed to global warming, linking climate change to a new structure of mycotoxin-producing mould species across the world. In the future, more pronounced climate changes may alter host resistance and host-pathogen interaction, and have a significant impact on the development of toxicogenic moulds and the production of mycotoxins as their secondary metabolites. The newly emerging climatological situation is attracting increasing attention, demanding new diagnostic tools and new insights into the biological characteristics of cultivated crops and the genetics of toxicogenic moulds. In Europe, the climate conditions are highly favourable for the growth of
Aspergillus flavus, bringing increased future risk of contamination of cereals with highly toxic aflatoxins. Meanwhile, the profile of mycotoxigenic species of Fusarium is beginning to change significantly, and increased reports of contamination with $F$. graminearum in northern and central Europe are particularly worrisome. Given the obvious climate change, further research is needed that will include predictive models with several variables, to provide an appropriate future approach to the strategy of preventing contamination by toxic moulds and mycotoxins in food and feed.

Key words: climate change; mycotoxins; moulds; environmental conditions; geographical areas; prevention 